\title{
KAPABILITAS DINAMIK, KINERJA INOVASI, DAN KINERJA PERUSAHAAN JASA LOGISTIK DI INDONESIA (Suatu Kerangka Penelitian)
}

\author{
Darjat Sudrajat \\ Management Department, School of Business and Management, BINUS University \\ Jln. K. H. Syahdan No. 9, Palmerah, Jakarta Barat 11480 \\ sudrajat.darjat@yahoo.com
}

\begin{abstract}
Market value of logistics services business in Indonesia in 2012 is estimated amount of USD 2.76 billion with an average growth of $12.1 \%$ per year. The industry is estimated growth in compound annual growth rate (CAGR) of $9.6 \%$ or about Rp2,042 trillion in 2015. The attractive market conditions and business opportunities have not been harnessed yet by local players optimally. On the contrary, one by one the local players have been bankruptcy due to unable to compete with foreign logistics services companies. Based on data of Indonesian Logistics and Forwarder Association (ILFA), it is currently registered about 3,000 members, but about 50\% of them are still active, while $50 \%$ of them are nonactive and getting problems. Of which are still active, not more than 20 companies are ready to compete with foreign logistics services companies. The problem is especially concerning human resource, networks, technology, and capital competencies. In line with that, the fundamental issues examined in this research are how the relationships of dynamic capabilities, innovation performance, and firm performance conceptually in the logistics service industry in Indonesia. To be able to answer the problems, it is necessary to research theoretically how each relationship of these three aspects in order to obtain a research model or framework. Thus the research framework can be used as a reference to construct hypotheses for further research. Based on the literature study, it can be concluded that dynamic capabilities directly affect innovation performance, in which the variables of dynamic capabilities encompass adaptive capabilities, absorptive capabilities, and innovative capabilities. In addition, dynamic capabilities can also directly affect the firm performance but can also indirectly impact on firm performance through innovation performance.
\end{abstract}

Keywords: dynamic capabilities, adaptive capabilities, absorptive capabilities, innovative capabilities, firm performance

\begin{abstract}
ABSTRAK
Nilai pasar untuk bisnis jasa logistik di Indonesia pada 2012 diperkirakan sekitar 2,76 miliar dolar Amerika dengan rata-rata pertumbuhan 12,1\% per tahun. Industri ini diperkirakan akan mengalami pertumbuhan compound annual growth rate (CAGR) sebesar 9,6\% atau mencapai 2.042 triliun rupiah pada 2015. Kondisi pasar dan peluang bisnis yang menarik tersebut ternyata masih belum dapat dimanfaatkan para pemain lokal secara optimal. Bahkan sebaliknya, para pemain local berguguran satu-persatu karena kerasnya persaingan terutama karena tekanan dari perusahaan jasa logistik asing. Berdasarkan data Asosiasi Logistik dan Forwarder Indonesia (ALFI), sekarang ini tercatat jumlah sekitar 3.000 perusahaan sebagai anggota. Namun sekitar 50\% yang masih aktif, sedangkan 50\% sedang mengalami kesulitan dan sudah gulung tikar. Dari yang masih aktif tersebut, tidak lebih dari 20 perusahaan yang sudah siap bersaing dengan perusahaan jasa logistik asing. Permasalahannya adalah terutama menyangkut kompetensi sumber daya manusia, jejaring kerja, teknologi, dan modal. Sehubungan dengan itu, penelitian membahas bagaimana secara konseptual hubungan kapabilitas dinamik, kinerja inovasi, dan kinerja perusahaan pada industri jasa logistik di Indonesia. Untuk menjawab permasalahan tersebut perlu dikaji secara teoretis bagaimana hubungan masing-masing dari ketiga aspek tersebut sehingga diperoleh suatu model atau kerangka penelitian. Dengan demikian kerangka penelitian tersebut dapat digunakan sebagai acuan untuk mengembangkan hipotesis untuk proses penelitian lebih lanjut. Berdasarkan studi literatur yang dilakukan, kapabilitas dinamik dapat berpengaruh langsung terhadap kinerja inovasi, dengan variabel untuk kapabilitas dinamik meliputi kapabilitas adaptif (adaptive capabilities), kapabilitas absorptif (absorptive capabilities), dan kapabilitas inovatif (innovative capabilities). Selain itu, kapabilitas dinamik juga dapat berpengaruh secara langsung terhadap kinerja perusahaan tetapi dapat berpengaruh secara tidak langsung juga terhadap kinerja perusahaan melalui kinerja inovasi.
\end{abstract}

Kata kunci: kapabilitas dinamik, kapabilitas adaptif, kapabilitas absorptif, kapabilitas inovatif, kinerja perusahaan 


\section{PENDAHULUAN}

Perubahan pasar yang radikal, tingkat persaingan yang makin ketat dan luas, dan eskalasi tuntutan pelanggan terhadap kualitas produk dan pelayanan yang superior merupakan tantangan baru dan berbeda dari sebelumnya yang dihadapi oleh para manajer dan eksekutif puncak setiap perusahaan dan organisasi sekarang ini dalam merumuskan strategi perusahaannya. Perusahaan yang bertahan hidup dan tumbuh dalam kondisi seperti ini adalah yang memahami dan melakukan perubahan serta menciptakan inovasi.

Peluang terbesar dalam bisnis sekarang ini bukan tergantung pada perbaikan efisiensi dari yang sudah dikerjakan, tetapi dengan merangkul perubahan-perubahan yang terjadi di luar (Fisk, 2006). Oleh sebab itu, orientasi pasar merupakan perspektif bisnis yang sangat penting bagi perusahaan, yaitu menjadikan para pelanggan sebagai pusat perhatian bagi keseluruhan operasi perusahaan. Menurut Cravens dan Piercy (2009), suatu perusahaan adalah berorientasi pasar ketika budaya penciptaan nilai pelanggan yang superior dijalankan secara sistematis dan menyeluruh pada perusahaan yang bersangkutan. Dalam konteks ini, proses inovasi di perusahaan merupakan aspek yang sangat penting dalam usaha menghasilkan produk-produk baru guna memenuhi tuntutan pelanggan yang terus berubah.

Sekarang ini kondisi tersebut sedang dihadapi juga oleh perusahaan-perusahaan jasa logistik di Indonesia. Perusahaan Jasa Logistik (Third Party Logistics/Logistics Service Provider) adalah pihak yang ditunjuk oleh pemilik barang untuk menyediakan jasa transportasi dan servis lainnya termasuk pergudangan, persiapan dokumen, kepabeanan, pengepakan, labeling, dan sebagainya. Industri jasa logistik sementara ini secara hukum mengacu kepada istilah Jasa Pengurusan Transportasi (JPT), yang berdasarkan Keputusan Menteri Perhubungan No KM/10 Tahun 1988 didefinisikan sebagai usaha yang ditujukan untuk mewakili kepentingan pemilik barang, untuk mengurus semua kegiatan yang diperlukan bagi terlaksananya pengiriman dan penerimaan barang melalui transportasi darat, laut, dan udara yang dapat mencakup kegiatan penerimaan, penyimpanan, sortasi, pengepakan, penandaan pengukuran, penimbangan, pegurusan penyelesian dokumen, penerbitan dokumen angkutan,klaim asuransi, atas pengiriman barang serta penyelesaian tagihan dan biaya-biaya lainnya berkenaan dengan pengiriman barang-barang tersebut sampai dengan diterimanya barang oleh yang berhak menerimanya.

Segmentasi pasar jasa logistik bila didasarkan pada keluasan jasanya terdiri dari segmensegmen classic outsourcing (jasa pergudangan, pengiriman, dan distribusi), advance service (classic outsorcing + jasa pengepakan, pemasangan label, dan testing), full/integrated service (Frost \& Sullivan). Berdasarkan layanan yang ditawarkan, perusahaan logistik juga dapat dibedakan menjadi empat tipe layaknya piramida. Lapisan pertama disebut basic service atau outsourcing model yang dikenal dengan istilah logistics service provider (LSP). Rata-rata perusahaan logistik lokal di Indonesia baru memasuki tahap ini. Kedua, value-added atau Third Party Logistics (3PL). Ketiga, lead logistics atau lead logistics provider (LLP). Perusahaan yang mencapai level ketiga ini sudah sangat canggih dan bisnis logistiknya terintegrasi. Contoh untuk level ini hanya dijumpai di perusahaan logistik luar negeri. Keempat atau tahap tertinggi adalah advance service atau fourth party logistics provider (4PL). Sedangkan jika didasarkan pada derajat kompleksitas aktivitas logisik dan derajat penyertaan perusahaan jasa logistik dalam melakukan aktivitas logistik, dapat dibedakan pada segmensegmen perusahaan yang memiliki tingkat kompleksitas aktivitas logistik yang tinggi/kompleks dengan derajat penggunaan perusahaan jasa logistik yang minim atau minor, perusahaan-perusahaan yang memiliki tingkat kompleksitas aktivitas logistik menengah dengan derajat penggunaan perusahaan jasa logistik yang besar, dan perusahaan-perusahaan yang memiliki tingkat kompleksitas aktivitas logistik yang rendah (sederhana) dengan derajat penggunaan perusahaan jasa logistik yang rendah. 
Pertumbuhan pasar jasa logistik di suatu negara sangat dipengaruhi oleh pertumbuhan ekonomi negara tersebut khususnya dan pertumbuhan ekonomi global pada umumnya. Adapun selama tahun 2012, pertumbuhan ekonomi Indonesia berada di kisaran 6,3\% dan pertumbuhan ekonomi global berada di kisaran 3,5\%. Secara umum, biaya logistik suatu negara adalah sekitar 20\% dari PDB negara yang bersangkutan. Jadi jika PDB Indonesia tahun 2011 adalah 7.427 triliun, biaya logistik sekitar 1.485 triliun. Angka itulah yang secara umum mencerminkan besarnya pasar jasa logistik di Indonesia, bahkan berdasarkan perkiraan persentase biaya logistik dari PDB di Indonesia kemungkinan lebih besar sekitaran 25\% s.d. $30 \%$. Nilai pasar untuk bisnis ini diperkirakan pada 2012 adalah sekitar 2,76 miliar dolar Amerika dengan rata-rata pertumbuhan 12,1 \% per tahun. Industri jasa logistik sendiri akan mengalami pertumbuhan compound annual growth rate (CAGR) sebesar 9,6\% atau mencapai 2.042 triliun rupiah pada 2015 (Frost \& Sullivan, 2012).

Adapun estimasi persentase, besarnya pasar, dan pertumbuhan untuk segmen classic outsourcing adalah sekitar $70 \%$ dari total pasar dengan nilai 1,93 miliar dolar Amerika dan pertumbuhan $12 \%$ per tahun, advance services sekitar $20 \%$ dari total pasar dengan nilai sebesar 0,55 miliar dolar Amerika dan pertumbuhan 16,7\% per tahun, full services (integrated services) adalah sekitar 10\% dengan nilai 0,28 miliar dolar Amerika dan pertumbuhan 22,56\% per tahun. Industri logistik sendiri akan mengalami pertumbuhan compound annual growth rate (CAGR) sebesar 9,6\% atau mencapai 2.042 triliun rupiah pada 2015 (Frost \& Sullivan). Sektor minyak dan gas Indonesia memiliki potensi terbesar bagi penyedia jasa logistik, pengiriman domestik diperkirakan akan meraih keuntungan besar pada 2011 yang para kontraktor industri minyak dan gas mengeluarkan 1,5 miliar dolar Amerika untuk jasa transportasi laut di Indonesia pada 2010 dan pemilik kapal lokal mendapatkan keuntungan sekitar 700 juta dolar Amerika dari nilai kontrak. Sedangkan untuk tahun ini jasa logistik berpotensi mencapai 3,2 miliar dolar Amerika dari industri minyak dan gas. Sektor lainnya yang menjadi primadona diangkut oleh penyedia layanan logistik adalah batu bara dan kelapa sawit. Pada 2009 Indonesia telah mengekspor 230 juta ton, sementara hingga September 2010 telah dikapalkan 209,4 juta ton.

Adapun fakor-faktor kunci keberhasilan yang perlu dimiliki oleh perusahaan jasa logistik untuk dapat memenangkan persaingan ke depan adalah sumber daya manusia yang berkualitas terutama dalam bidang logistik, pengalaman perusahaan yang memadai, modal kerja yang kuat, kepemilikan aset atau fasilitas logistik yang memadai, sertifikasi kualitas internasional, jejaring kerja yang luas baik domestik maupun internasional, sistem dan teknologi informasi yang memadai, administrasi keuangan yang komprehensif, legalitas perusahaan yang lengkap, dan daya saing harga yang kuat. Beberapa peluang yang dapat dimanfaatkan ke depan oleh perusahaan-perusahaan jasa logisik di Indonesia adalah pertumbuhan ekonomi Indonesia yang relatif stabil, kondisi keamanan dan politik semakin baik, tingkat outsourcing kegiatan logistik oleh perusahaan-perusahaan manufaktur akan makin meningkat, kondisi ekonomi di daerah akan mengalami perkembangan yang signifikan sehubungan dengan pelaksanaan otoritas daerah yang makin luas, ekspansi ke pasar ASEAN dan China makin mudah karena kesepakatan AFTA dan CAFTA, perkembangan teknologi pendukung (logistik, SCM, CRM, dan sebaginya) makin pesat, dan kemudahan-kemudahan dari pemerintah dalam rangka kegiatan ekspor maupun impor. Sehingga secara umum pasar bisnis jasa logistik di Indonesia cukup menarik.

Kondisi pasar dan peluang-peluang bisnis yang menarik tersebut ternyata masih belum dapat dimanfaatkan oleh para pemain lokal secara optimal. Bahkan sebaliknya, para pemain local berguguran satu-persatu karena kerasnya persaingan terutama karena tekanan dari perusahaanperusahaan jasa logistik asing. Berdasarkan data Asosiasi Logistik dan Forwarder Indonesia (ALFI), sekarang ini tercatat jumlah sekitar 3.000 perusahaan sebagai anggota, namun sekitar $50 \%$ yang masih aktif, sedangkan 50\% lagi sedang mengalami kesulitan dan sudah gulung tikar. Dari yang masih aktif tersebut, tidak lebih dari 20 perusahaan yang sudah siap bersaing dengan perusahaan jasa logistik asing. Permasalahannya adalah terutama menyangkut kompetensi sumber daya manusia, jejaring kerja, teknologi, dan modal. 
Berdasarkan kondisi-kondisi tersebut, perusahaan-perusahaan jasa logistik Indonesia memerlukan suatu pendekatan yang terintegrasi untuk pengembangan bisnisnya baik untuk menjaga loyalitas pelanggan yang sekarang maupun untuk meraih pelanggan-pelanggan baru, sehingga bisa menggarap pasar yang prospektif tersebut dengan lebih optimal. Untuk memenuhi tuntutan tersebut, peningkatan kapabilitas dan kompetensi perusahaan dalam menghasilkan inovasi-inovasi yang berkelanjutan sangat diperlukan sehingga dapat mendorong kinerja perusahaan secara keseluruhan.

Sehubungan dengan itu, permasalahan mendasar yang dibahas dalam penelitian ini adalah bagaimana hubungan kapabilitas dinamik, kinerja inovasi, dan kinerja perusahaan pada industri jasa logistik di Indonesia. Untuk dapat menjawab permasalahan tersebut, perlu dikaji secara teoretis bagaimana hubungan masing-masing dari ketiga aspek tersebut sehingga diperoleh suatu model atau kerangka penelitian. Dengan demikian kerangka penelitian tersebut dapat digunakan sebagai acuan untuk mengembangkan hipotesis untuk proses penelitian lebih lanjut.

\section{Kerangka Konseptual}

Dalam persaingan bisnis global seperti dewasa ini, perusahaan selain memerhatikan struktur industri, juga harus melihat perspektif internal dengan menelaah secara saksama sumber daya yang dimilikinya dan bagaimana mengombinasikannya untuk memperoleh kompetensi inti dan keunggulan kompetitif (Prahalad dan Hamel, 1997). Untuk itu, diperlukan paradigma baru untuk memahami bagaimana keunggulan kompetitif dapat dicapai. Pemenang persaingan dalam pasar global adalah perusahaan yang dapat memberikan responsiveness yang tepat waktu dan cepat dengan inovasi produk yang fleksibel, yang dipadukan dengan kapabilitas manajemen untuk melakukan koordinasi yang efektif serta menempatkan kompetensi internal maupun eksternal secara tepat. Kapabilitas ini yang dirujuk sebagai kapabilitas dinamik (dynamic capabilities), yang menekankan pada dua aspek kunci yaitu "dynamic" dan "capabilities".

Menurut Sampurno (2010), “dynamic" merujuk pada kapasitas untuk memperbarui kompetensi terkait jika terjadi perubahan lingkungan bisnis; melakukan respons inovatif jika diperlukan karena adanya tuntutan waktu dan kecepatan masuk pasar; perubahan teknologi yang cepat, persaingan masa depan dan determinasi pasar yang sulit. Sedangkan "capabilities” menekankan pada peran kunci dari manajemen strategis dalam adaptasi yang tepat, integrasi dan rekonfigurasi internal dan skill organisasional, sumber daya dan kompetensi fungsional sehingga terjadi kesesuaian (match) dengan perubahan lingkungan.

Dalam dekade terakhir ini makin banyak pemikiran dari para pakar strategi dan manajemen yang menyatakan bahwa kapabilitas dinamis merupakan jantung strategi perusahaan, penciptaan nilai dan keunggulan bersaing (misalnya Teece, 2009; Eisenhardt dan Martin, 2000; Winter, 2003; Helfat et al., 2007). Secara konseptual penelitian-penelitian mengenai kapabilitas dinamik didasarkan pada konsep resource-base view (Wernerfelt, 1984; Barney, 1991; Peteraf, 1993; Amit \& Shoemaker, 1993). Suatu perspektif yang menyimpulkan bahwa keunggulan bersaing perusahaan-perusahaan dibangun melalui sumber daya-sumber daya baik yang tangible maupun intangible.

Adapun yang dimaksud dengan dynamic capabilities adalah kemampuan perusahaan dalam mengintegrasikan, membangun, dan merekonfigurasi kompetensi internal dan eksternal untuk menghadapi lingkungan yang berubah cepat (Teece, 2009). Menurut Zollo dan Winter (2002):

"A dynamic capability is a learned and stable pattern of collective activity through which the organization systematically generates and modifies its operating routines in pursuit of improved effectiveness."

Dengan demikian kapabilitas dinamik merefleksikan kemampuan organisasi untuk meraih bentuk baru keunggulan kompetitif yang inovatif sebagai hasil (given) path dependencies dan posisi 
pasar. Menurut Helfat (2007), kapabilitas dinamik adalah kemampuan suatu organisasi untuk menciptakan, memperpanjang, atau memodifikasi basis sumber dayanya untuk maksud-maksud tertentu. Istilah strategic menurut Teece dan Pisano (1997) adalah kemampuan perusahaan yang harus diarahkan pada kebutuhan pengguna (konsumen), bersifat unik (sehingga produk dan jasa yang dihasilkan dihargai tanpa banyak melihat pada persaingan), sulit ditiru (sehingga keuntungan dapat ditentukan dengan mengabaikan adanya pesaing). Keunggulan daya saing perusahaan menurut Teece dan Pisano (1997) berasal dari kemampuan dinamik yang berakar didalam kegiatan rutin perusahaan tersebut, melekat dalam proses-proses kegiatan perusahaan, dan terkondisikan selama beroperasinya atau berdirinya perusahaan. Selanjutnya Teece dan Pisano menyatakan bahwa terdapat berbagai faktor yang menentukan kemampuan dinamik perusahaan dan dikelompokkan dalam tiga kategori, yaitu: proses, posisi, dan alur (path).

Dimensi strategi dari perusahaan adalah proses-proses manajerial dan organisasional, posisi saat ini, serta alur (path) yang tersedia untuk itu. Yang dimaksud dengan proses manajerial dan organisasional adalah bagaimana segala sesuatu diselesaikan di perusahaan, atau mengacu kepada hal yang secara rutin dilakukan, atau pola-pola pembelajaran (learning) dan praktik atau kegiatan perusahaan saat ini. Yang dimaksud sebagai posisi mengacu pada sumbangan teknologi dan hak kekayaan intelektual saat ini, sumbangan konsumen, serta hubungannya dengan pemasok. Pada akhirnya alur (path) mengacu pada alternatif strategi yang tersedia untuk perusahaan, dan seberapa menarik peluang yang ada pada masa yang akan datang.

Menurut Teece (2009), keunggulan kompetitif perusahaan terkait dengan aspek manajerial dan proses organisasional, yang diperkuat oleh posisi aset spesifik dan bagaimana alur (path) untuk mencapainya. Aspek manajerial dan proses organisasional mengandung pengertian bagaimana hal itu dilaksanakan dalam perusahaan atau terkait dengan pola praktik dan pembelajaran yang ada pada saat ini. Proses organisasional mempunyai tiga peranan: koordinasi/integrasi (konsep static), pembelajaran (konsep dinamis), dan rekonfigurasi (konsep transformasional).

Identifikasi dan eksploitasi sumber daya strategis tersebut memungkinkan untuk mengembangkan strategi persaingan yang berbasis pada sumber daya perusahaan. Untuk itu penting bagi perusahaan untuk mengidentifikasi, mengetahui, dan menganalisis sumber daya dan kemampuan mereka untuk menemukan yang superior atau berbeda (different). Lebih lanjut mereka dapat menciptakan kegiatan yang unik atau aktivitas yang superior dibandingkan dengan pesaingnya dengan hasil yang lebih baik (Barney, 2003). Prahalad dan Hamel (1997), untuk resource ini menggunakan terminologi yang berbeda yaitu core competencies (kompetensi inti). Kompetensi inti adalah pembelajaran kolektif dalam organisasi, khususnya bagaimana mengoordinasikan skill produksi yang beragam (diverse) dan mengintegrasikan multiple stream dari berbagai teknologi. Dengan kata lain kompetensi inti adalah seperangkat (bundle) skill dan teknologi yang membuat perusahaan mampu memberikan benefit tertentu kepada customer.

Sedangkan kapabilitas, menurut Hitt et al (2005), merepresentasikan seperangkat integrated resources yang digunakan untuk melaksanakan aktivitas-aktivitas penting. Kapabilitas ini menyatu dalam skill dan knowledge pekerja yang ada di perusahaan. Kompetensi perusahaan berbasis pada kapabilitas, rutinitas organisasional, dan kemampuan untuk belajar. Oleh karena itu, perusahaan harus mengembangkan kompetensi intinya secara terus menerus dan atau menyiapkan perubahan dan mengembangkan sumber daya yang baru lainnya, untuk mempertahankan daya saing.

Untuk memperoleh sumber daya yang bernilai dan heterogen, perusahaan harus melakukan akuisisi atau mengembangkannnya sendiri. Untuk mengembangkan sumber daya nirwujud, sebagai yang tersulit untuk ditiru memerlukan pembelajaran (learning) yang kuat dan membangun knowledge (Teece, 2009). Ini berarti perusahaan harus mempunyai kapabilitas untuk belajar agar memiliki absorptive capacity yang tinggi/kuat. Seberapa lama perusahaan memiliki keunggulan kompetitif berkaitan langsung dengan kekuatan isolating mechanism (Rumelt, 1984), termasuk spesifitas 
perusahaan, causal ambiguity, kompleksitas sosial, path dependence, dan time compression diseconomies yang melindungi sumber daya (resources) dari imitasi (Dierickx \& Cool, 1989).

Esensi dari eksekusi strategi yang baik (good strategy execution) adalah membangun dan memperkuat core competence dan kapabilitas perusahaan. Dalam konteks ini manajemen harus proaktif untuk meningkatkan (upgrading) kapabilitas yang ada untuk memperbaiki implementasi strategi sekaligus mengembangkan kompetensi dan kapabilitas baru menghadapi perubahan dan tantangan eksternal perusahaan. Dapat dikatakan bahwa dynamic capabilities adalah versi evolusi dari resource-based view dengan pendekatan inside dan eksternal

Perusahaan yang beroperasi dalam lingkungan yang berubah memerlukan struktur dan praktik yang memiliki fleksibilitas dan kemampuan respons yang cepat. Perusahaan harus secara kontinu melakukan perbaikan (improvement) pada proses maupun produknya, termasuk mengembangkan produk baru sesuai dengan dinamika kebutuhan pasar. Keberhasilan dalam merespons perubahan pasar tergantung pada kemampuan perusahaan dalam mengonversikan knowledge ke arah inovasi yang dapat memperkuat keunggulan kompetitif perusahaan. Menurut dynamic capabilities view, perusahaan memerlukan kapabilitas dinamik dalam bentuk aset, proses, dan struktur yang memungkinkan perusahaan memiliki fleksibilitas strategic dalam menghadapi turbulensi lingkungan.

Identifikasi mengenai dimensi kapabilitas spesifik perusahan yang dapat menjadi sumber keunggulan penting untuk dilakukan. Selain itu, perlu dipahami bagaimana kombinasi antara kompetensi dan sumber daya dapat dikembangkan, ditempatkan, dan dilindungi untuk menciptakan daya saing yang berkelanjutan. Perspektif “dynamic capabilities” menekankan eksploitasi kapabilitas spesifik yang ada, baik internal maupun eksternal agar dapat menghadapi lingkungan yang berubah cepat.

Menurut Wang dan Ahmed (2007), kapabilitas dinamik dapat dianalisis dengan tiga elemen utama, yaitu adaptive capabilities, absorptive capabilities, dan innovative capabilities. Kemampuan adaptif (adaptive capabilities) adalah kemampuan perusahaan untuk mengidentifikasi dan memanfaatkan pasar yang sedang berkembang, termasuk kemampuan perusahaan dalam mengadaptasi lingkup produk-pasar mereka untuk merespons peluang eksternal, memindai pasar, memantau pelanggan dan pesaing serta mengalokasikan sumber daya untuk kegiatan pemasaran, dan untuk merespons perubahan kondisi pasar secara cepat. Selain itu, mengevaluasi apakah sistem manajemen perusahaan dapat merespons dengan cepat perubahan pasar dan berkembang dengan cepat dalam menanggapi pergeseran prioritas bisnis.

Menurut Cohen dan Levinthal (1989), absorptive capabilities merupakan kemampuan perusahaan dalam mengenali nilai informasi baru eksternal, memahaminya, dan memanfaatkannya untuk tujuan komersial. Sehingga absorptive innovation merupakan kemampuan dalam mengevaluasi dan memanfaatkan pengetahuan diluar yang sebagian besar merupakan fungsi dari tingkat pengetahuan sebelumnya. Oleh karena itu, pengembangan kemampuan ini adalah aspek tersendiri yang menuntut suatu investasi terus menerus untuk mempertahankan kemampuan teknis dalam bidang tersebut. Absorptive capabilities sering tercermin dalam inovasi perusahaan dan kemampuannya dalam memanfaatkan pengetahuan baru dan penting untuk kegiatan inovatif perusahaan (Cohen \& Levinthal, 1989).

Innovative capability merupakan kemampuan perusahaan dalam mengembangkan produk dan atau pasar baru, melalui penyelarasan orientasi inovasi yang strategis dengan proses dan perilaku inovatif (Wang \& Ahmed, 2004). Dodgson et al (2008) menyatakan bahwa innovative capabilities adalah seperangkat keahlian yang digunakan oleh perusahaan untuk memformulasikan dan mengimplementasikan suatu strategi inovasi yang melibatkan kreasi, ekstensi, dan modifikasi dari semua sumber daya yang digunakan untuk inovasi. Sejalan dengan ini, Bell (2009) menyatakan bahwa innovation capabilities merupakan kapabilitas yang diperlukan untuk menciptakan, mengembangkan, 
dan mengimplementasikan konfigurasi teknologi produk dan proses baru dan mengimplementasikan perubahan-perubahan dan perbaikan-perbaikan teknologi yang sudah digunakan.

Menurut Pekka dan Thomas (2006), innovative capabilities mencakup di samping kemampuan teknologi juga aspek-aspek manajemen dan organisasi agar berpindah dari kesempatan teknologi menjadi innovasi. Menurut mereka innovative capability suatu perusahaan tergantung pada sistem inovatif, yang ada dalam resource perusahaan. Innovative capability perusahaan tergantung pada sistem inovasinya, yang melekat pada resource perusahaan, sistem manajemen, struktur organisasi dan kegiatan rutin perusahaan. Kapabilitas inovatif dinyatakan sebagai kapabilitas perusahaan untuk menciptakan nilai pelanggan dengan mengembangkan dan mengenalkan kepada pasar produk-produk dan jasa-jasa baru atau mengurangi biaya-biaya yang menjadi beban proses penciptaan nilai (Pekka \& Thomas, 2006). Menurut Hagedoorn dan Duysters (2002), kapabilitas inovatif adalah menyangkut keahlian dan kompetensi tertentu yang berhubungan dengan pengembangan dan pengenalan proses dan produk baru. Menurut Subramanian dan Youndt (2005), Sen dan Egelhoff (2000), kapabilitas inovatif dapat diklasifikasikan dalam dua tipe yang berbeda, yaitu inkremental dan radikal. Kapabilitas inovasi inkremental berfokus pada perbaikan proses dan produk sekarang; kapabilitas inovasi radikal berfokus pada pengembangan produk-produk baru berdasarkan teori-teori dan konsep-konsep yang berbeda secara menyeluruh.

Sementara untuk konsep inovasi, Barringer dan Ireland (2013) menyatakan bahwa inovasi adalah proses penciptaan sesuatu yang baru. Dalam dunia bisnis saat ini, inovasi sebagai suatu disiplin, belum mencapai tahap perkembangan yang diharapkan dalam memenuhi kebutuhan tertentu yang sangat mendesak (de Bes \& Kotler, 2011). Inovasi selalu terkait dengan beberapa praktik yang nilainya membumi. Ini adalah tentang membuat alat, produk atau proses baru, melahirkan sesuatu yang 'baru' yang memungkinkan manusia untuk mencapai sesuatu yang tidak mampu dicapai sebelumnya (Tidd \& Bessant, 2009). Inovasi bukan mengenai munculnya produk baru atau yang lebih baik, tetapi mengenai pemecahan masalah yang harus muncul pertama kali (Silverstein, et al, 2009).

Inovasi adalah keberhasilan sosial dan ekonomi berkat diperkenalkannya atau ditemukannya cara-cara baru atau kombinasi baru dari cara-cara lama dalam menstransformasikan input menjadi output sedemikian rupa sehingga berhasil menciptakan perubahan besar atau perubahan drastis dalam hubungan antara nilai guna atau nilai manfaat (yang dipersepsikan oleh konsumen dan/atau pengguna) dan nilai moneter atau harga (Fontana, 2011). Definisi ini menjelaskan bahwa inovasi tidak saja berarti kebaruan atau sesuatu yang baru, barang dan/atau jasa baru atau sistem produksi baru atau cara memasarkan yang baru. "Kebaruan" itu perlu disertai dengan dampak positif bagi konsumen dan produsen; "kebaruan" itu harus menciptakan nilai guna bagi konsumen dan nilai tambah bagi produsen; "kebaruan" yang menghasilkan kesuksesan ekonomi dan sosial, pada konteks inovasi dan penciptaan nilai tingkat individu, organisasi, dan masyarakat (society).

Perusahaan berinovasi untuk menciptakan relasi antara nilai guna dan harga (nilai moneter) yang lebih tinggi atas produk yang dihasilkannya bagi konsumen (consumers) dan/atau pengguna (users) yang ditargetkan, yang pada akhirnya produk tersebut tidak hanya akan bermanfaat bagi konsumen dan/atau pengguna tetapi juga produsen. Proses inovasi didorong oleh kebutuhan untuk memahami bagaimana sesuatu bekerja atau mengapa tidak bias; untuk menumbuhkan pendapatan, mengurangi biaya, atau meningkatkan produktivitas; untuk memecahkan masalah pelanggan; atau untuk menjaga orang-orang hidup sehat dan aman (Estrin, 2009). Menurut Estrin (2009), terdapat lima nilai inti dari inovasi yaitu questioning, risk taking, openness, patience, dan trust. Adapun dimensidimensi inovasi adalah sebagai berikut. Inovasi produk adalah perubahan-perubahan dalam segala hal (produk/jasa) yang ditawarkan perusahaan; inovasi proses adalah perubahan-perubahan dalam caracara yang diciptakan dan disampaikan; inovasi posisi adalah perubahan-perubahan dalam konteks pengenalan produk/jasa; dan inovasi paradigma adalah perubahan-perubahan yang mendasari mental model yang menggambarkan hal yang dilakukan perusahaan (Tidd \& Bessant, 2009). Menurut Fontana (2011), terdapat dua prinsip inovasi, yaitu proses penciptaan nilai dilakukan secara bekerja 
sama dengan konsumen; dan tidak satu pun perusahaan yang memiliki pengetahuan, keahlian, keterampilan, dan sumber daya yang cukup untuk melakukan penciptaan nilai secara bersama dengan konsumen sehingga setiap perusahaan harus belajar untuk mengakses sumber daya dari berbagai sumber.

Oleh karena itu kemampuan inovasi didefinisikan sebagai kemampuan untuk terus mentransformasikan pengetahuan dan ide-ide menjadi produk baru, proses dan sistem untuk kepentingan perusahaan dan para pemangku kepentingannya. Kemampuan inovasi tidak hanya kemampuan untuk menjadi sukses dalam menjalankan sebuah newstream bisnis, atau untuk mengelola kemampuan mainstream. Kemampuan inovasi adalah tentang sintesis kedua paradigma operasi. Inovator yang berprestasi harus memahami hubungan ini. Tantangan untuk semua entrepreneur adalah membangun organisasi yang efektif dan inovatif. Organisasi yang efektif mampu menstransformasi kegiatan entrepreneurial korporat kedalam strategi perusahaannya, yang merupakan hal mendasar dalam mengembangkan pendekatan-pendekatan yang kreatif dan inovatif yang didesain untuk mengembangkan ide-ide dan cara-cara baru dalam melakukan sesuatu (Hisrich \& Kearney, 2013).

\section{Kinerja Inovasi}

Metrik Inovasi terdiri dari seperangkat alat dan sistem untuk mengukur kapasitas inovatif dari suatu organisasi (De Bes, 2011). Metrik tersebut dapat dikelompokkan menjadi empat kategori, yaitu metrik yang mengukur hasil inovasi dari sudut pandang ekonomi, metrik yang mengukur intensitas inovasi dalam suatu departemen dan unit bisnis atau organisasi, metrik yang mengukur efektivitas kegiatan inovatif dan investasi, dan metrik yang mengukur seberapa luas budaya kreatif dalam suatu organisasi.

Metrik ekonomi mengukur hasil inovasi yang positif dan negatif dari inovasi yang menggunakan variable dari laporan keuangan perusahaan, misalnya penjualan perusahaan dari peluncuran produk baru, profit dari peluncuran produk baru, penjualan perusahaan dari inovasi-inovasi produk baru lainnya. Intensitas berkenaan dengan kuantitas inovasi tanpa mempertimbangkan hasilhasil yang diperoleh. Jumlah paten, yaitu jumlah inovasi dalam produk, servis, pengalaman pelanggan, dan model proses atau bisnis.

Efektivitas, metrik ini mencoba mengukur profit dengan hubungannya terhadap penggunaan sumber daya dengan sasaran memaksimalkan output inovasi dengan meminimalkan input, misalnya tingkat keberhasilan dalam produk baru, waktu masuk ke pasar, rata-rata investasi per proyek. Budaya, dalam hal ini metric, mengenai aspek-aspek yang berhubungan dengan budaya kreatif di perusahaan, misalnya persentase tenaga kerja yang menghasilkan ide-ide baru dan tingkat ide-ide baru per karyawan per tahun.

Menurut Anthony et al (2008) bahwa tantangan bagi perusahaan yang ingin meningkatkan kemampuan mereka dalam menciptakan pertumbuhan melalui inovasi adalah bahwa banyak perusahaan menggunakan metrik untuk mengukur inovasi namun dengan cara yang salah dan berisiko tinggi. Metrik inovasi dapat dibagi berdasarkan tiga kategori, yaitu input, proses, dan output. Untuk kategori input, misalnya sumber daya keuangan yang dialokasikan untuk inovasi, sumber daya manusia yang difokuskan pada inovasi. Kategori proses, misalnya kecepatan proses, kedalaman proses penciptaan ide, dan keseimbangan portofolio inovasi. Kategori output, misalnya jumlah produkproduk atau servis-servis baru yang diluncurkan, persentase revenue dari kategori inti dari produk baru, dan persentase keuntungan dari pelanggan baru. 


\section{METODE PENELITIAN}

Penelitian menggunakan metode studi literatur yang berhubungan dengan aspek-aspek kapabilitas dinamik, kinerja inovasi, dan kinerja perusahaan. Berdasarkan studi literatur tersebut kemudian dibuat suatu pola hubungan di antara faktor-faktor tersebut sebagai kerangka penelitian lebih lanjut.

\section{HASIL DAN PEMBAHASAN}

\section{Hubungan Kapabilitas Dinamik dengan Kinerja Inovasi}

Beberapa hasil penelitian menyatakan bahwa kapabilitas dinamik (dynamic capabilities) memengaruhi kinerja inovasi suatu perusahaan (Cabral, 2010; Chang et al., 2012). Menurut Cabral (2010), suatu perusahaan yang memiliki tingkat kapabilitas adaptif, absorptif, dan inovatif yang tinggi, pengembangan inovasinya tidak hanya berfokus orientasi pada tingkat keuntungan yang tinggi tetapi juga pada lingkungan dan ekuitas sosial. Dalam hal ini, perusahaan mengarahkan strategi inovasinya berfokus pada hasil-hasil yang berkelanjutan, yang kapabilitas dinamik menjadi pusat pengembangan kapabilitas perusahaan, yang menghasilkan tingkat kontinuitas penciptaan produk-produk atau jasa baru yang lebih tinggi. Sebaliknya, tingkat kapabilitas adaptif, absorptif, dan inovatif yang rendah menyebabkan tingkat kontinuitas penciptaan produk dan jasa baru yang rendah juga. Oleh karena itu, hasil inovasi yang berkelanjutan adalah lebih signifikan pada perusahaan-perusahaan yang tingkat kapabilitas adaptif, absorptif, dan inovatifnya tinggi, sehingga perusahaan-perusahaan yang menjalankan strategi inovatif lah yang akan berperan.

Menurut Chang et al (2012), perusahaan-perusahaan yang fokus pada pelanggan cenderung menyusun kembali kapabilitas organisasinya, yaitu dengan menginovasi produk dan jasanya agar sesuai dengan keinginan dan pengalaman pengunaan pelanggan. Inovasi dan kapabilitas dinamik perusahaan-perusahaan secara signifikan dipengaruhi oleh posisi dan alur perkembangan sebelumnya dalam industri tersebut. Adapun aspek-aspek kapabilitas dinamik (dynamic capabilities) yang berpengaruh terhadap kinerja inovasi adalah adaptive capabilities, absorptive capabilities, dan innovative capabilities (Wang dan Ahmed, 2007; Oktemgil dan Gordon, 1997; Gibson dan Birkinshaw, 2004; Pekka dan Thomas, 2006; Bell, 2009; Cabral, 2010).

\section{Hubungan Kapabilitas Dinamik dengan Kinerja Perusahaan}

Berdasarkan beberapa penelitian ternyata kapabilitas dinamik pun dapat berpengaruh secara langsung terhadap kinerja perusahaan (Protogerou et al., 2008; Teece \& Pisano, 1994; Stam et al., 2007; Ambrosini, Bowman, \& Collier, 2009; Teece, 2007). Menurut Protogerou et al. (2008), kapabilitas dinamik adalah anteseden untuk kompetensi fungsional yang lebih lanjut berpengaruh secara signifikan terhadap kinerja perusahaan, sehingga kapabilitas dinamik tidak signifikan berpengaruh langsung terhadap kinerja perusahaan.

Menurut Teece dan Pisano (1994), keunggulan bersaing perusahaan berasal dari kapabilitas dinamik yang tertanam pada kinerja sehari-hari yang tinggi dalam perusahaan, melekat dalam proses perusahaan, dan dikondisikan oleh proses perkembangannya. Menurut Stam, Gibcus, dan Garnsey (2007), pertumbuhan perusahaan baru berhubungan dengan kapabilitas dinamik dan pertumbuhan ekonomi penting lainnya. Kapabilitas dan pertumbuhan paling memungkinan ditemukan adalah kegiatan R\&D pertama kali dan aliansi antarperusahaan. 
Menurut Ambrosini dan Bowman (2009), kinerja kapabilitas dinamik tidak akan begitu saja memengaruhi perbaikan kinerja. Perbaikan ini akan terjadi yang hanya ada suatu kesesuaian dari kedinamisan yang diharapkan dan kedinamisan yang sesungguhnya, dan hanya perusahaan yang sesungguhnya memiliki kapabilitas dinamik yang dibutuhkan, harapannya adalah suatu hasil kinerja yang positif. Menurut Teece (2007), kapabilitas dinamik memungkinkan bisnis perusahaan tercipta, tersebar, dan terlindungi intangible asset yang mendukung kinerja perusahaan jangka panjang yang superior.

\section{Hubungan Kinerja Inovasi dengan Kinerja Perusahaan}

Beberapa hasil penilitian menyatakan bahwa kinerja inovasi berpengaruh terhadap kinerja perusahaan (Lawson \& Samson, 2001; Gunday, 2010; Corsino, 2008; Gera dan Gu, 2004; Vasquez, Santos, \& Alvarez, 2001). Menurut Lawson dan Samson (2001), organisasi-organisasi yang berkembang dan berinvestasi secara terencana dan eksplisit pada aspek-aspek kapabilitas inovasi, baik secara individual maupun kolektif, mempunyai kemungkinan yang lebih besar dalam mencapai hasil inovasi yg berkelanjutan sebagai mesin kinerja perusahaan. Menurut Gunday (2010), terdapat pengaruh yang positif dari inovasi terhadap kinerja perusahaan dalam industri pabrikasi. Menurut Corsino (2008), inovasi produk yang diperdagangkan dalam waktu cepat secara positif berpengaruh terhadap aliran revenue perusahaan pada perusahaan-perusahaan semikonduktor.

Menurut Gera \& Gu (2004), perusahaan-perusahaan yang menggabungkan ICT dalam tingkat tinggi dengan perubahan organisasi mempunyai insiden yang tinggi dari perbaikan produktivitas dan tingkat inovasi. Perusahaan-perusahaan yang mengkombinasikan ICT tingkat tinggi dan keahlian pekerjanya mempunyai kinerja perusahaan yang lebih baik. Menurut Vasquez, Santos, dan Alvarez (2001), orientasi pasar secara signifikan memengaruhi daya inovatif perusahaan yang selanjutnya memengaruhi tingkat inovasi perusahaan dan keinovatifan produk baru. Sedangkan kedua variabel tersebut berpengaruh langsung terhadap kinerja perusahaan. Gambar 1 dan 2 berikut berturut-turut menunjukkan model innovation capability dan market orientation effects.

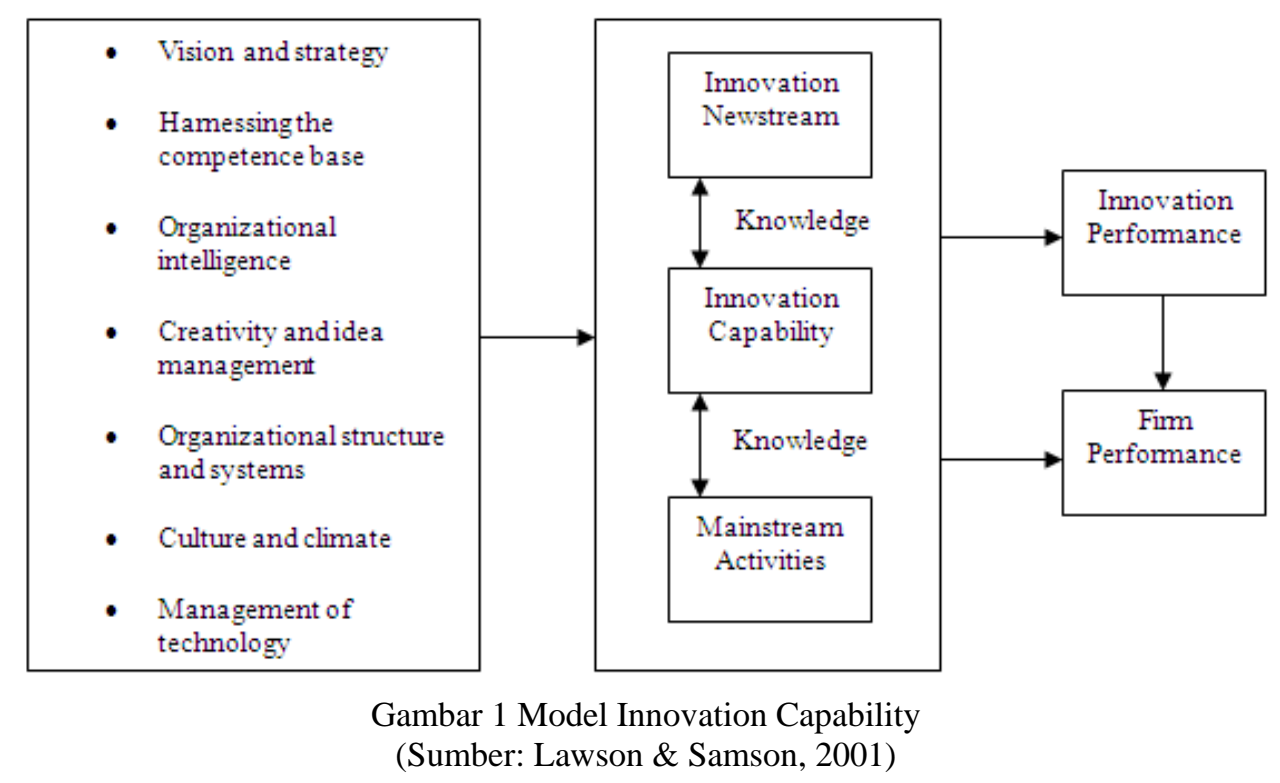




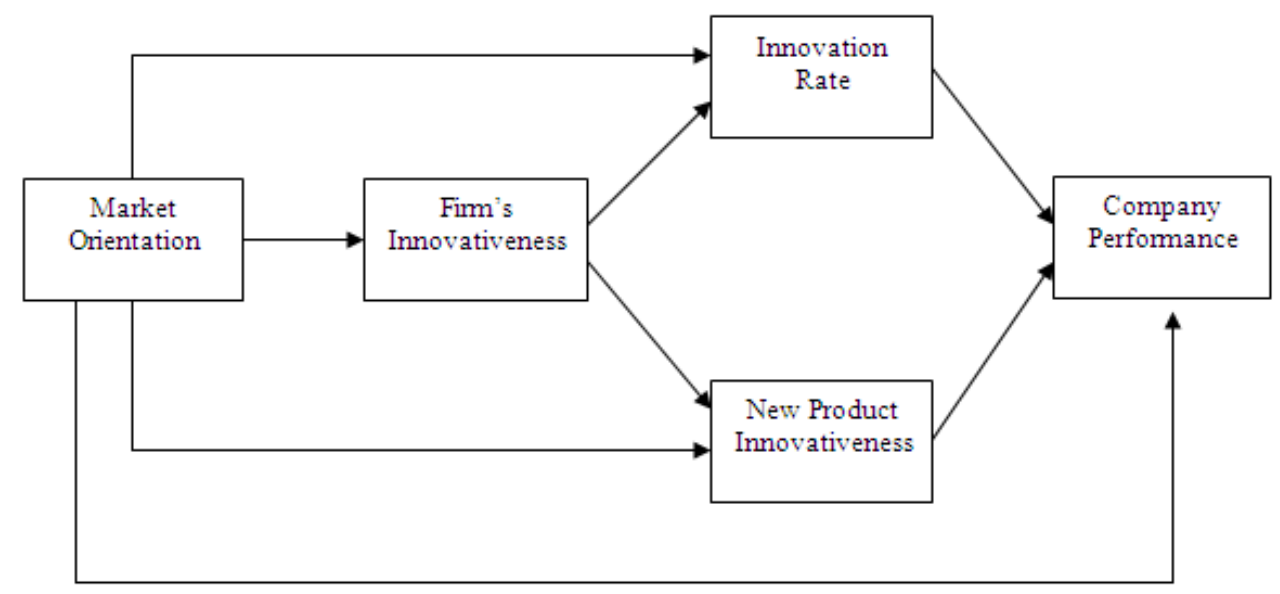

Gambar 2 Market Orientation Effects

(Sumber: Vazquez, Santos, \& Alvarez, 2001)

\section{SIMPULAN}

Berdasarkan studi literatur dan pembahasan, disimpulkan terdapat hubungan langsung antara kapabilitas dinamik dengan kinerja inovasi. Variabel untuk kapabilitas dinamik meliputi kapabilitas adaptif (adaptive capabilities), kapabilitas absorptif (absorptive capabilities), dan kapabilitas inovatif (innovative capabilities). Sedangkan hubungan antara kapabilitas dinamik dan kinerja perusahaan dapat secara langsung maupun tidak langsung melalui kinerja inovasi. Adapun model atau kerangka hubungan antara kapabilitas dinamik, kinerja inovasi, dan kinerja perusahaan dapat digambarkan sebagai berikut.

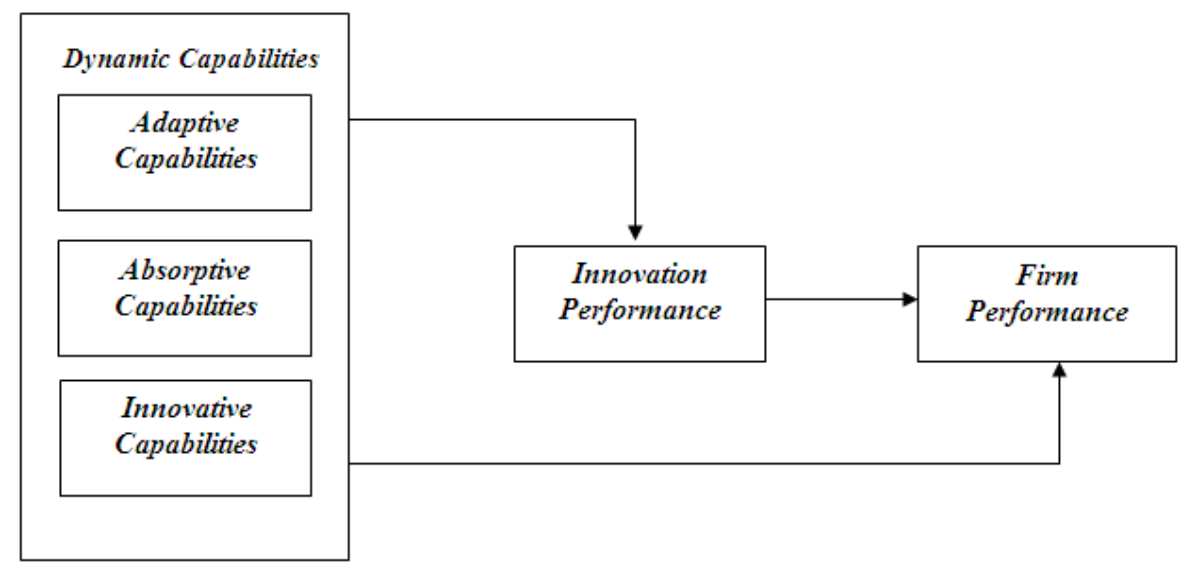

Gambar 3 Hubungan Antara Kapabilitas Dinamik, Kinerja Inovasi, dan Kinerja Perusahaan

\section{DAFTAR PUSTAKA}

Ambrosini, V., Bowman, C., and Collier, N. (2009). Dynamic Capabilities: an Exploration of How Firms Renew Their Resource Base. British Journal of Management, 20, S9S24.

Amit, R., and Schoemaker, P. J. (1993). Strategic Assets and Organisational Rent. Strategic Management Journal. 14, 33-46. 
Anthony, S. D., et al. (2008). The Innovator's Guide to Growth: Putting Disruptive Innovation to Work. Boston, USA: Harvard Business School.

Barney, J. B. (1991). Firm Resources and Sustained Competitive Advantage. Journal of Management. 17, 99-120.

Barringer, B. R., and Ireland, R. D. (2013). Entrepreneurship: Successfully Launching New Ventures. Fourth Edition. England: Pearson Education.

Bell, M. (2009). Innovation Capabilities and Directions of Development. STEPS Working Paper 33. Brighton: STEPS Centre.

Cabral, J. E. de Oliveira. (2010). Firm's Dynamic Capabilities, Innovative Types and sustainability: A Theoretical Framework. XVI International Conference on Industrial Engineering and Operations Management. Brazil.

Chang, A., et al. (2012). Dynamic Capabilities and Innovation Performance of Publishing Firms in Digital Age. International Journal.

Cohen, W. M., and Levinthal, D. A. (1989). Innovation and Learning: The Two Faces of R\&D. The Economic Journal. 99, 569-596.

Corsino, M. (2008). Product Innovation and Firm Growth: Evidence from the Integrated Circuits Industry. DRUID Working Paper No. 08-06.

Cravens, D. W., Piercy, N. F. (2009). Strategic Marketing. $9^{\text {th }}$ Edition. New York: McGrawHill/Irwin.

De Bes, F. T., and Kotler, P. (2011). Winning at Innovation: The A-to-F Model. Macmillan, New York: Palgrave.

Dierickx, I., and Cool, K. (1989). Asset Stock Accumulation and Sustainability of Competitive Advantage. Management Science, 35. USA.

Dodgson, M., Gann, D., Salter, A. (2008). The Management of Technological Innovation. Oxford: Oxford University Press.

Eisenhardt, K., and Martin, J. (2000). Dynamic Capabilities: What Are They? Strategic Management Journal, 21, 1105-1121.

Estrin, J. (2009). Closing the Innovation Gap: Reigniting The Spark of Creativity in a Global Economy. New York: McGraw-Hill.

Fisk, P. (2006). Marketing Genius. England: Capstone (A Wiley Company).

Fontana, A. (2011). Innovate We Can! How to Create Value Through Innovation in Your Organization and Society. Edisi Revisi. Bekasi: Cipta Inovasi Sejahtera.

Gera, S., and Gu, W. (2004). The Effect of Organizational Innovation and Information Technology on Firm Performance. International Productivity Monitor, 9, Canada.

Gibson, C., and Birkinshaw, J. (2004). The Antecedents, consequences, and Mediating Role of Organizational Ambidexterity. Academy Management Journal, 47(2), 209-226. 
Gunday, G., et al. (2010). Effects of Innovation Types on Firm Performance. International Journal. Turkey.

Hagedoorn, J., and Duysters, G. (2002). External Sources of Innovative Capabilities: The Preference for Strategic Alliances or Mergers and Acquisitions. Journal of Management Studies, 39(2), 167-188.

Helfat, C. E., et al. (2007). Dynamic Capabilities: Understanding Strategic Change in Organizations. London: Blackwell.

Helfat, E., dan Peteraf, M. A. (2009). Understanding Dynamic Capabilitis: Progress Along a Developmental Path. Sage.

Hisrich, R. D., and Kearney, C. (2013). Corporate Entrepreneurship: How to Create a Thriving Entrepreneurial Spirit Throughout Your Company. New York: McGraw-Hill.

Hitt, M. A., et al. (2005). Strategic Management: Competitiveness and Globalization. Sixth Edition. South-Western, USA.

Lawson, B., and Samson, D. (2001). Developing Innovation Capability in Organizations: A Dynamic Capabilities Approach. International Journal of Innovation Management, 5(3), 377400.

Oktemgil, M., and Gordon, G. (1997). Consequences of High and Low Adaptive Capability in UK Companies. European Journal of Marketing, 31(7), 445-466.

Pekka, O., and Thomas, R. (2006). Innovation as a Source of Competitive Advantage in Wood Products Manufacturing Industries. Proceedings of the $1^{\text {st }}$ COST Action E51 Joint MC and WG Meeting, 12-14 October 2006, 67-87.

Peteraf, M. A. (1993). The Cornerstones of Competitive Advantage: A Resource-Based View. Strategic Management Journal. 12, 95-117.

Prahalad, C.K., and Hamel, G. (1990). The Core Competence of the Corporation. Harvard Business Review. May-June 1990.

Protogerou, A., et al. (2008). Dynamic Capabilities and Their Indirect Impact on Firm Performance. Druid, Denmark.

Sampurno. (2010). Manajemen Stratejik: Menciptakan Keunggulan Bersaing yang Berkelanjutan. Yogyakarta: Gadjah Mada University Press.

Sen, F., and Egelhoff, W. G. (2000). Innovative Capabilities of A Firm and the Use of Technical Alliances. IFE Transactions Engineering Management, 47(2), 174-183.

Silverstein, D., Samuel, P., DeCarlo, N. (2009). The Innovator's Toolkit: 50+ Techniques for Predictable and Sustainable Organic Growth. New Jersey: John Wiley \& Sons.

Subramanian, M., and Youndt, M. A. (2005). The Influence of Intellectual Capital on the Types of Innovative Capabilities. Academy of Management Journal, 48(3), 450-463.

Teece, D. J. (2007). Explicating Dynamic Capabilities: The Nature and Microfoundations of (Sustainable) Enterprise Performance. Strategic Management Journal, 28, 1319-1350. 
Teece, D. J. (2009). Dynamic Capabilities and Strategic Management: Organizing for Innovation and Growth. New York: Oxford University Press.

Teece, D. J., and Pisano, G. (1994). The Dynamic Capabilities of Firms: An Introduction. Industrial and Corporate Change, 3(3), 537-56.

Teece, D.J., Pisano, G and Shuen, A. (1997). Dynamic Capabilities and Strategic Management. Strategic Management Journal, 18, 509-533.

Tidd, J., and Bessant, J. (2009). Managing Innovation: Integrating Technological, market and Organizational Change. $4^{\text {th }}$ Edition. England: John Wiley \& Sons.

Vazquez, R., Santos M. L., Alvarez, L. I. (2001). Market Orientation, Innovation and Competitive Strategies in Industrial Firms. Journal of Strategic Management, 9, 69-90.

Wang, C. L., and Ahmed, P. K. (2007). Dynamic Capabilities: A Review and Research Agenda. The International Journal of Management Reviews, 9(1), 31-51.

Wernerfelt, B. (1984). A Resource-Based View of the Firm. Strategic Management Journal, 5, $171-$ 180.

Winter, S. (2003). Understanding Dynamic Capabilities. Strategic Management Journal, 24, 991- 995.

Zollo, M., and Winter, S. G. (2002). Deliberate Learning and the Evolution of Dynamic Capabilities. Organization Science, 13(3). 